\title{
Professional Development of Computer Studies Teachers for Effective Implementation of Computer Education Curriculum in Secondary Schools
}

\author{
NGBARABARA, Prince Boniface \\ Office of the Vice-Chancellor, Federal University Otuoke, Bayelsa State
}

\begin{abstract}
The study determined professional development of Computer Studies teachers for effective implementation of Computer Education curriculum in secondary schools in Enugu Education Zone, Enugu State. Three research questions guided the study. Descriptive survey research design was adopted. The population for the study was 182 Computer Studies teachers. There was no sampling as the population size was manageable. The research instrument was a structured questionnaire titled "Strategies for Enhancing Professional Development of Computer Studies Teachers' Questionnaire (SEPDCSTQ)". Three experts validated the instrument and an overall reliability correlation co-efficient of 0.94 was obtained using Cronbach's Alpha. Mean ratings and standard deviation were used to answer the research questions. The study revealed that educational supervision, mentoring services and in-service training enhances the professional development of Computer Studies teachers for effective implementation of Computer Education curriculum in secondary schools in Enugu Education Zone, Enugu State to a high extent. The study concludes that educational supervision, mentoring services and inservice training are strategies for enhancing the professional development of Computer Studies teachers. The study recommended that in-service training via workshops, seminars and so on should be regularly organized for teachers of Computer Studies so as to enhance their professional development for effective implementation of Computer Education curriculum in secondary schools and to help them develop experiences in the teaching field.
\end{abstract}

Keywords: Professional Development, Computer Studies, Teachers, Implementation, Computer Education, Curriculum.

DOI: $10.7176 / \mathrm{JEP} / 10-20-01$

Publication date:July $31^{\text {st }} 2019$

\section{Introduction}

Education is a major instrument for tackling unemployment, poverty and ignorance. It is on this basis that the Federal Republic of Nigeria (FRN, 2013) outlined in her National Policy on Education, the cardinal aims of education which include among others: the development of intellectual capacity of individuals to understand and appreciate their environment; and the acquisition of both physical and intellectual skills which will enable individuals to develop into useful members of the community. These skills are acquired in formal education settings from primary, secondary and tertiary institutions such as universities, polytechnics and colleges of education. For the purpose of this study, the focus will be on secondary education.

Secondary education is one aspect of educational institutions in Nigeria that is designed specifically to train and prepare students for middle-level services in both manufacturing and service industries. One of the objectives of secondary education according to Olowe (2011) is the acquisition of both physical and intellectual skills which will enable individuals to be self-reliant and useful members of the society. It must be emphasized that secondary education in Nigeria is for six years duration, junior secondary school (3 years) and senior secondary school (3 years). The two stages are both vocational and academic in nature. The broad goal of secondary education as stated in the National Policy on Education is to prepare the individual citizen for useful living within the society and preparation for higher education (FRN, 2013). Computer Education is one of the educational programme offered at the secondary school level.

Computer Education according to Anikweze (2014) involve teaching and inculcating in the learner the basic skills required to independently manipulate the computer to achieve educational goals. The author further stated that computer education is aimed at making students acquire skills and competencies required in this digital world of competitiveness. Such basic skills and competencies upon graduation make the students conversant with terms and practices embedded in the world of computer. Computer Education is therefore organized to enable people understand the function, uses and limitations of the computer and to provide an opportunity for the study of the modern methods of information processing. To ensure effective implementation of Computer Education curriculum, there is need for professional development of Computer Studies teachers.

Professional development according to Glatthorn in Anikweze (2014) broadly refers to the professional growth that a teacher achieves as a result of gaining increased experience and examining his or her teaching systematically. Anikweze further noted that professional development includes both formal and informal 
experiences. The formal experiences include activities such as attending workshops and professional meetings, mentoring and so on. Informal experiences on the other hand relates to reading professional publications, watching television documentaries that are related to one's academic discipline and so on. To ensure professional development of Computer Studies teachers for effective implementation of Computer Education curriculum, there is need for functional strategies to be adopted.

Strategies are activities that are implemented towards the achievement of stated measurable objectives (Olowe, 2011). They describe the actions to be taken in order to achieve each objective. Strategies thus, refer to specific ways or action plans that could be adopted to improve the professional development of teachers. Olowe thus identified three major strategies for improving the professional development of teachers. These strategies include educational supervision, mentoring and in-service training.

Kweku and Dwamena (2014) described educational supervision as the stimulation of professional growth and development of teachers, selection and revision of educational objectives, materials of instruction, methods of teaching, and the evaluation of instruction. Modern educational supervision according to Bailey (2006) is characterized among others as a technical process aimed at improving teaching and learning through the care, guidance and stimulation of continued development for not only teachers but also any other person having an impact on the educational context. Essentially, the major aim of educational supervision is to enhance teaching and learning and the achievement of educational goals and objectives.

Mentoring is a training and development relationship that enhances an individual's professional growth (Okurame, 2008). To Baugh and Sullivan (2010), mentoring relationships can be formal or informal. The formal mentoring are those created to ensure that more employees have the opportunity to reap the benefits of the relationship. They are formed through a planned matching or assignment of mentors and protégés (the younger and less experienced partner in the union) by an organization. Informal mentoring relationships are those which evolve naturally from shared admiration, aspiration, values and interests.

In-service training is defined as a workshop for employed professionals, para-professionals and other practitioners to acquire new knowledge, better methods and so on (Kweku \& Dwamena, 2014). It helps in improving skills toward more effective, efficient and competent rendering of service in various fields and to diverse groups of people. With respect to educational setting, in-service training is designed to benefit a specific group of teachers in a particular school. A good in-service training is meant to enhance the professional development of teachers across all levels of education.

In view of the importance of Computer Education, there is need to ensure continued professional development of Computer Studies teachers to ensure effective implementation of the curriculum. It is against this background that the study focused on professional development of Computer Studies teachers for effective implementation of Computer Education curriculum in secondary schools in Enugu Education Zone, Enugu State.

\section{Statement of the Problem}

Despite the importance attached to Computer Studies by the government, the academic performances of students in both internal and external examinations have not been encouraging in recent times. The poor academic performance on the other hand has been attributed to the teachers' ineffectiveness and poor professional development. For instance, Onuigbo (2012) observed that the general academic performances of students in Computer Studies during the Senior Secondary School Certificate Examination (SSCE) conducted by West African Examination Council in South-south States such as Bayelsa, Edo and Delta between 2013 to 2017 showed a poor academic performance. In fact, the observed poor academic performance when juxtaposed with the perceived high standard of interest in the subject leaves one with the impression that the objectives of teaching the subject will not be achieved if the trend continues.

It is generally believed that teaching is effective only to the extent that the desired changes in students towards expectations are realized and that when the students have not learnt, the teacher has not taught. The continued falling standard of education is viewed by many as a clear reflection of the ineffectiveness of the teaching profession. The ineffectiveness of the teaching profession has been attributed to lack of adequate strategies for the improvement of teachers' professional development. All these problems associated with the falling standard of education need solutions for the objectives of Computer Education to be realized. It is on this basis that the researcher tends to determine the extent professional development of Computer Studies teachers could enhance effective implementation of Computer Education curriculum in secondary schools in Enugu Education Zone, Enugu State.

\section{Purpose of the Study}

The main purpose of the study was to determine professional development of Computer Studies teachers for effective implementation of Computer Education curriculum in secondary schools in Enugu Education Zone, Enugu State. Specifically, the study determined the extent:

1. Educational supervision enhances professional development of Computer Studies teachers for 
effective implementation of Computer Education curriculum in secondary schools in Enugu Education Zone, Enugu State.

2. Mentoring services enhance professional development of Computer Studies teachers for effective implementation of Computer Education curriculum in secondary schools in Enugu Education Zone, Enugu State.

3. In-Service training enhances professional development of Computer Studies teachers for effective implementation of Computer Education curriculum in secondary schools in Enugu Education Zone, Enugu State.

\section{Research Questions}

The following research questions guided the study:

1. To what extent does educational supervision enhance professional development of Computer Studies teachers for effective implementation of Computer Education curriculum in secondary schools in Enugu Education Zone, Enugu State?

2. To what extent does mentoring services enhance professional development of Computer Studies teachers for effective implementation of Computer Education curriculum in secondary schools in Enugu Education Zone, Enugu State?

3. To what extent does in-service training enhance professional development of Computer Studies teachers for effective implementation of Computer Education curriculum in secondary schools in Enugu Education Zone, Enugu State?

\section{Method}

This study adopted a descriptive survey research design. A descriptive survey research design according to Nworgu (2015), is one in which a group of people or items is studied by collecting and analyzing data from only a few people or items considered to be representative of the entire group using questionnaire or interview. This design was considered appropriate for this study since it sought to explore the opinions of the respondents on the strategies for enhancing the professional development of Computer Studies teachers for effective implementation of Computer Education curriculum in secondary schools. The population for this study is 182 Computer Studies teachers in public secondary schools in Enugu Education Zone, Enugu State. The population size is manageable; therefore, there was no sampling. The instrument for data collection was a structured questionnaire titled "Strategies for Enhancing Professional Development of Computer Studies Teachers Questionnaire" (SEPDCSTQ). The instrument was validated by three experts, two in Science Education and one in Measurement and Evaluation all from faculty of Education, Enugu State University of Science and Technology, Enugu State. Their comments enhanced the content validity of the instrument. To establish the internal consistency of the instrument, the Cronbach Alpha formula was used to analyze the data using the Statistical Package for Social Sciences (SPSS) version 21 and obtain reliability coefficients values of $0.95,0.93$ and 0.94 for clusters B1, B2 and B3 respectively with an overall coefficient value of 0.94 . The questionnaire was structured on a five-point rating scale, with response categories as "Very High Extent", "High Extent", "Moderate Extent", "Low Extent" and "Very Low Extent". The administration of the instrument was carried out personally by the researcher with the help of two research assistants. Out of 182 copies of the questionnaire administered on the respondents, a total of 177 copies were successfully retrieved and were used for data analysis. Data collected regarding the research questions were analyzed using mean and standard deviation. In order to answer the research questions, a decision rule based on mean ratings between 4.50-5.00, were regarded as very high extent, items with mean ratings of 3.50-4.49 were considered as high extent and items with 2.50-3.49 were regarded as moderate extent. Furthermore, items with mean ratings of 1.50-2.49 and 0.50-1.49 were considered as low extent and very low extent respectively.

\section{Results}

\section{Research Question 1:}

To what extent does educational supervision enhance professional development of Computer Studies teachers for effective implementation of Computer Education curriculum in secondary schools in Enugu Education Zone, Enugu State? 
Table 1: Mean rating of respondents on the extent educational supervision enhances professional development of Computer Studies teachers for effective implementation of Computer Education curriculum in secondary schools. $N=177$

S/N Aspects of Educational Supervision

\begin{tabular}{|c|c|c|}
\hline Mean & SD & Decision \\
\hline 4.00 & .45 & $\begin{array}{l}\text { High } \\
\text { Extent }\end{array}$ \\
\hline 4.30 & .46 & $\begin{array}{l}\text { High } \\
\text { Extent }\end{array}$ \\
\hline 4.30 & .78 & $\begin{array}{l}\text { High } \\
\text { Extent }\end{array}$ \\
\hline 3.80 & .40 & $\begin{array}{l}\text { High } \\
\text { Extent }\end{array}$ \\
\hline 4.10 & .54 & $\begin{array}{l}\text { High } \\
\text { Extent }\end{array}$ \\
\hline 4.30 & .64 & $\begin{array}{l}\text { High } \\
\text { Extent }\end{array}$ \\
\hline 4.20 & .87 & $\begin{array}{l}\text { High } \\
\text { Extent }\end{array}$ \\
\hline 3.80 & .75 & $\begin{array}{l}\text { High } \\
\text { Extent }\end{array}$ \\
\hline
\end{tabular}

1. Making teachers familiar with different techniques of classroom management

2. Helps teachers to discern ways of adapting instruction to individual students learning pace

3. Trains teachers to be able to use effective methods to help students to overcome their learning difficulties

4.10

High Exten

\section{Cluster Mean}

The data in Table 1 above shows that all the items have mean ratings ranging from 3.80 to 4.30 meaning that all the items enhance the professional development of Computer Studies teachers for effective implementation Computer Education curriculum to a high extent. The cluster mean score of 4.10 indicates that, in the opinion of the respondents, educational supervision is a strategy to enhance professional development of Computer Studies teachers for effective implementation of Computer Education curriculum in secondary schools in Enugu Education Zone, Enugu State. The standard deviations of 0.40 to 0.87 shows that the respondents are homogenous in their responses.

\section{Research Question 2}

To what extent does mentoring services enhance professional development of Computer Studies teachers for effective implementation of Computer Education curriculum in secondary schools in Enugu Education Zone, Enugu State? 
Table 2: Mean rating of respondents on the extent mentoring services enhance professional development of Computer Studies teachers for effective implementation of Computer Education curriculum in secondary schools. $\mathrm{N}=177$

\begin{tabular}{|c|c|c|c|c|}
\hline $\mathbf{S} / \mathbf{N}$ & Aspects of Mentoring Services & Mean & SD & Decision \\
\hline 1. & $\begin{array}{l}\text { Encouragement and sponsoring of Computer Studies } \\
\text { teachers for professional conferences }\end{array}$ & 4.20 & .48 & High Extent \\
\hline 2. & Granting of study leaves & 4.10 & .43 & High Extent \\
\hline 3. & Sponsoring of research and academic publications & 4.40 & .45 & High Extent \\
\hline 4. & $\begin{array}{l}\text { Orientation services for less experienced Computer } \\
\text { Studies teachers }\end{array}$ & 3.49 & .46 & $\begin{array}{l}\text { Moderate } \\
\text { Extent }\end{array}$ \\
\hline 5. & Assigning representative functions to junior staff & 4.23 & .52 & High Extent \\
\hline 6. & $\begin{array}{l}\text { Pairing of junior staff with senior staff in various } \\
\text { departmental committees }\end{array}$ & 4.13 & .44 & High Extent \\
\hline 7. & $\begin{array}{l}\text { Sharing of professional knowledge and skills with new } \\
\text { teachers }\end{array}$ & 4.60 & .41 & $\begin{array}{l}\text { Very High } \\
\text { Extent }\end{array}$ \\
\hline 8. & $\begin{array}{l}\text { Providing advisory services to help new teachers improve } \\
\text { on their career }\end{array}$ & 4.50 & .50 & $\begin{array}{l}\text { Very High } \\
\text { Extent }\end{array}$ \\
\hline 9. & $\begin{array}{l}\text { Creating channels to ensure constant communication } \\
\text { flow between experienced and less experience teachers }\end{array}$ & 3.54 & .52 & High Extent \\
\hline 10. & $\begin{array}{l}\text { Recognition of outstanding performances to increase job } \\
\text { satisfaction of new teachers }\end{array}$ & 3.55 & .53 & High Extent \\
\hline Cluste & Mean & 4.07 & & High Extent \\
\hline
\end{tabular}

The data in Table 2 above shows that all the item numbers $1,2,3,5,6,9$ and 10 have mean ratings ranging from 3.54 to 4.40 meaning that all the items enhances the professional development of Computer Studies teachers for effective implementation Computer Education curriculum to a high extent. Items 7 and 8 have mean ratings of 4.60 and 4.50 respectively meaning that they contribute to a very high extent while item 4 has a mean rating of 3.49 which means that it contributes to a moderate extent. The cluster mean score of 4.07 indicates that, in the opinion of the respondents, mentoring services is a strategy to enhance professional development of Computer Studies teachers for effective implementation of Computer Education curriculum in secondary schools in Enugu Education Zone, Enugu State. The standard deviations of 0.41 to 0.53 shows that the respondents are homogenous in their responses.

Research Question 3

To what extent does in-service training enhance professional development of Computer Studies teachers for effective implementation of Computer Education curriculum in secondary schools in Enugu Education Zone, Enugu State?

Table 3: Mean rating of respondents on the extent in-service training enhances professional development of Computer Studies teachers for effective implementation of Computer Education curriculum in secondary schools. $\mathrm{N}=177$

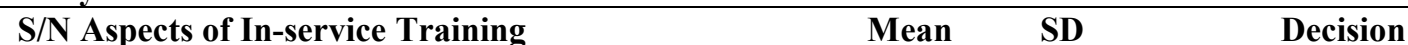

1. Training teachers on the usage of model instructional facilities

2. Organizing professional development programmes in research methodology and pedagogy

3. Organizing teachers for ICT trainings

4. Organizing in-service workshops and seminars for teachers

5. Organizing induction/ orientation for new teachers

$\begin{array}{lll}4.10 & .45 & \text { High Extent } \\ 4.40 & .40 & \text { High Extent } \\ 4.20 & .75 & \text { High Extent } \\ 3.80 & .40 & \text { High Extent }\end{array}$

Cluster Mean

$4.10 \quad .52$

High Extent

The data in Table 3 above shows that all the items have mean ratings ranging from 3.80 to 4.40 meaning that all the items enhances the professional development of Computer Studies teachers for effective implementation Computer Education curriculum to a high extent. The cluster mean score of 4.10 indicates that, in the opinion of the respondents, in-service training is a strategy to enhance professional development of Computer Studies teachers for effective implementation of Computer Education curriculum in secondary schools 
in Enugu Education Zone, Enugu State. The standard deviations of 0.40 to 0.75 shows that the respondents are homogenous in their responses.

\section{Discussion of Findings}

The data on Table 1 revealed that education supervision enhances the professional development of Computer Studies for effective implementation of Computer Education curriculum in secondary schools in Enugu Education Zone, Enugu State to a high extent. The results revealed the major aspects of educational supervision which the respondents indicated that enhances their professional development to a high extent. These include making teachers familiar with different techniques of classroom management, helps teachers to discern ways of adapting instruction to individual students learning pace, training teachers to be able to use effective methods to help students to overcome their learning difficulties and so on. This finding is in agreement with that of Appenteng (2012) whose study revealed that educational supervision exposes the teachers to different techniques of classroom management. The author noted that through educational supervision, teachers would be helped to always be in full control of their class. Thus, through educational supervision, Computer Studies teachers would be helped to use innovative teaching methods in delivering their instruction and get updated with current trends and issues in Computer Education curriculum. Therefore, educational supervision is one way to effectively train the classroom teachers in proper use of teaching methods.

The data on Table 2 revealed that mentoring services enhances the professional development of Computer Studies for effective implementation of Computer Education curriculum in secondary schools in Enugu Education Zone, Enugu State to a high extent. The results revealed the major aspects of mentoring services which the respondents indicated that enhances their professional development to a high extent. These include assigning representative functions to junior staff, pairing of junior staff with senior staff in various departmental committees, creating channels to ensure constant communication flow between experienced and less experienced teachers and so on. This finding is supported by Okurame (2008) who noted that a mentor should establish a good rapport with the protégés, assess their needs in consultation with other interested and appropriate parties, and end the mentoring relationship at the appropriate time and in an appropriate manner. Thus, each mentoring arrangement is unique, and its particular nature will be established according to the personalities of the two individuals concerned.

The data on Table 3 revealed that in-service training enhances the professional development of Computer Studies teachers for effective implementation of Computer Education curriculum in secondary schools in Enugu Education Zone, Enugu State to a high extent. The results revealed the major aspects of in-service training which the respondents indicated that enhances their professional development to a high extent. These include training teachers on the usage of model instructional facilities, organizing professional development programmes in research methodology and pedagogy and so on. This finding is in consonance with Abugieyi (2013) who carried out a study to evaluate the relevance of in-service training in enhancing the professional performance of lecturers in Colleges of Education in South-south, Nigeria. The findings of the study revealed that lecturers' professional performance are poor as a result of inadequate in-service training. This goes to show that adequate in-service training for computer studies teachers is essential towards enhancing their professional development for effective implantation of computer education curriculum in secondary schools.

\section{Conclusion}

Based on the findings of this study, it was concluded that educational supervision, mentoring services and inservice training are strategies for enhancing professional development of Computer Studies teachers. Thus, when the professional development of Computer Studies teachers are enhanced through these strategies, they would be fully competent and completely equipped to effectively implement Computer Education curriculum in secondary schools.

\section{Recommendations}

Based on the findings of this study, the following recommendations were made:

1. In-service training via workshops, seminars and so on should be regularly organized for Computer Studies teachers so as to enhance their professional development for effective implementation of Computer Education curriculum in secondary schools.

2. Educational supervision should be regularly organized with the intent of helping Computer Studies teachers develop experiences in the teaching field. This could be achieved by explaining the importance of current educational issues, identifying teachers' professional needs, and encourage them to engage in self-motivated learning so as to update their professional knowledge, skills and experience.

3. Enugu State government through the Secondary Education Management Board (SEMB) should establish a Mentoring Programme Office as a department in the Ministry of Education and to saddle it with the task of coordinating and evaluating the program and ensuring that mentoring services are 
provided in various secondary schools across the State.

4. Administrators of secondary schools should endeavor to mentor their staff well both old and new to aid their professional development and to avoid stagnation and burn out. This can be done via induction programmes, workshops and public enlightenment programmes.

\section{References}

Abugieyi, A. A. (2013). Teachers' Effectiveness and Students' Academic Performance in Public Secondary Schools in Delta State, Nigeria. Studies in Home Community and Science Journal, 3(2): 103-117.

Anikweze, C.M. (2014). Preparation of teachers for tertiary institutions in Nigeria: What Fafunwa would have loved to see. In N.A. Nwagwu \& U.M.O.Ivowi (Ed). Education in Nigeria: Development and challenges, 183-208. Lagos: Foremost Educational Services Ltd.

Appenteng, P. C. (2012). The importance of non-verbal communication in classroom management. Procedia social and behavioral sciences. Retrieved from http:// www. sciencedirect.com/science

Bailey, K, M. (2006). Supervision as an instrument of teaching - learning effectiveness: Challenges and way forward. Global Journal of Educational Research, 8(2), 15-20.

Baugh, S. G. \& Sullivan, S. E. (2011). Mentoring and career development, Career Development International, $10(6 / 7), 423-428$.

Federal Republic of Nigeria (2013). National policy on education. Lagos: NERDC Press.

Kweku, E.E., \& Dwamena, E. (2014). Effects of educational supervision on professional development. Perception of public basic school teachers at Winneba, Ghana. British Journal of Education, 2(6), 63-82. Retrieved from www.eajournals.org

Nworgu, B. G. (2015). Educational research: Basic issues and methodology. Owerri: Wisdom publishers.

Okurame, D.E. (2008). Mentoring in the Nigerian academia: experiences and challenges. International Journal of Evidence Based Coaching and Mentoring, 6(2), 45-56.

Olowe S.U. (2011). The agonies of Nigerian teachers. Ibadan: Heinemann Education Publishers Limited.

Onuigbo, C.C (2012). Impact of computer assisted instructions on the academic performance of students in Social Studies in Enugu State, Nigeria. Unpublished M.Ed Thesis, Ahmadu Bello University, Zaria, Kaduna State. 